\title{
The Influence of Female Directors and Institutional Pressures on Corporate Social Responsibility in Family Firms in Latin America
}

\author{
Isabel-María García-Sánchez ${ }^{1, * \mathbb{D}}$, Lázaro Rodríguez-Ariza ${ }^{2}$ (D) and María-del-Carmen Granada-Abarzuza ${ }^{3}$ \\ 1 IME-Instituto Multidisciplinar de Empresa, Departamento de Administración y Economía de la Empresa, \\ Campus Miguel de Unamuno, Universidad de Salamanca, 37007 Salamanca, Spain \\ 2 Departamento de Economía financiera y Contabilidad, Campus La Cartuja s/n, Universidad de Granada, \\ 18071 Granada, Spain; lazaro@ugr.es \\ 3 Departamento de Administración y Economía de la Empresa, Campus Miguel de Unamuno, \\ Universidad de Salamanca, 37007 Salamanca, Spain; cgranada@usal.es \\ * Correspondence: lajefa@usal.es
}

Citation: García-Sánchez,

Isabel-María, Lázaro

Rodríguez-Ariza, and

María-del-Carmen

Granada-Abarzuza. 2021. The

Influence of Female Directors and

Institutional Pressures on Corporate Social Responsibility in Family Firms in Latin America. Journal of

Risk and Financial Management 14: 28.

https://doi.org/10.3390/jrfm14010028

Received: 3 December 2020

Accepted: 4 January 2021

Published: 8 January 2021

Publisher's Note: MDPI stays neutral with regard to jurisdictional clai$\mathrm{ms}$ in published maps and institutional affiliations.

Copyright: $\odot 2021$ by the authors. Licensee MDPI, Basel, Switzerland. This article is an open access article distributed under the terms and conditions of the Creative Commons Attribution (CC BY) license (https:// creativecommons.org/licenses/by/ $4.0 /)$.

\begin{abstract}
This paper has two main aims. Firstly, we examine whether, given a critical mass of female board members, their presence has a different effect on the firm's CSR practices according to its family or non-family nature. We then consider whether the moderating role of the institutional environment in Latin America enhances the role of female directors in influencing the board's attitude towards CSR strategies. The results obtained-from a sample of 22,958 observations, corresponding to an unbalanced data panel of 5124 companies for the period 2010-2016-confirm our hypothesis and also highlight the existence of type I (organisational) and type II (institutional) compensation effects, which reduce or eliminate differences between family and non-family firms, whether or not they are located in Latin American countries.
\end{abstract}

Keywords: corporate social responsibility; family firms; female directors; board of directors; gender; corporate governance

\section{Introduction}

The concept of Corporate Social Responsibility (CSR) is widely accepted in business, as strategists take the view that promoting the social and environmental dimensions of a company's activity benefits both the firm and its stakeholders, in areas such as increased sales, enhanced corporate image and reputation and reduced perceptions of risk for investors, which in turn facilitates access to more favourable sources and conditions of finance (Malik 2015; Wang et al. 2015; Lins et al. 2017; Rodríguez-Gómez et al. 2020; García-Sánchez and García-Sánchez 2020).

According to García-Sánchez et al. (2020a, 2020b), these consequences arise because, on the one hand, market agents are highly sensitive to social and environmental issues and view companies that are committed to CSR as being less risky; in addition, the judicious application of CSR can allow companies to reduce information asymmetries among managers, the market and investors-when a company makes more information available about its ethical approach to business, its investors are reassured.

The composition of the board of directors significantly influences a firm's commitment to sustainability (Birindelli et al. 2018). For example, the presence of female directors on the board is known to impact on a company's social and environmental performance (Setó-Pamies 2015; Cuadrado-Ballesteros et al. 2017). In many cases, women have different values, skills and professional experience and are more sensitive to social concerns. All of these factors can have a positive influence on the firm's social and environmental performance (Boulouta 2013; Giannarakis et al. 2014). However, in many cases female directors form an exiguous minority and have very limited influence on 
CSR decision-making (Wei et al. 2017; Cook and Glass 2018). It has been estimated that at least three women are needed on the board for the female standpoint to be taken into account (Torchia et al. 2011). It has also been observed that the impact of gender diversity on boardroom decision making is significantly moderated by the organisational environment (Amorelli and García-Sánchez 2019).

In this context, we address the question of the role played by female directors in the family firm, an area of business organisation that has specific differentiating characteristics. These companies typically seek to preserve their social-emotional wealth (SEW), uphold the family's control and influence, defend the special identity of the firm and continue the dynasty (Gómez-Mejía et al. 2007). Family managers and board members are usually more averse to the loss of SEW than to financial loss, an outlook that can significantly affect the strategic decisions taken by the firm (Gómez-Mejía et al. 2011). Accordingly, family businesses may be more strongly committed to CSR and/or investment in longterm sustainable projects, as these mechanisms are believed to facilitate the subsequent transfer of the company to future generations (Kim et al. 2017; Binz et al. 2017). In addition, these policy decisions enhance the company's image (Cennamo et al. 2012), which is a significant consideration due to the close relationship perceived between the family's own reputation and the success and image of its business activities (Sharma and Sharma 2011; Marques et al. 2014).

For female directors to make a real impact on a company's decision making, there must be an appropriate environment for this to take place, in which their contributions are accepted and women are perceived to be equal, legitimate members of the board (Tsui et al. 2002). Within the family firm, in addition to the traditional advantages associated with women as a collective, the immaterial qualities they are believed to possess facilitate family relationships and hence a more informal management style (Rigby and Sanchís 2006). Accordingly, it is plausible to assume that these qualities, which are highly regarded within family firms, will enhance the role played by female directors when their presence achieves a critical mass in the business setting.

Moreover, these characteristics of the role and impact of female directors may be moderated by institutional pressures, which can determine both the functioning of boards of directors and the role of women in decision-making positions (Briano-Turrent and PolettiHughes 2017; Reyes-Bastidas and Briano-Turrent 2018; Uribe-Bohorquez et al. 2019). In this respect, the similarities and differences observed in the context of Latin American firms is of special interest, due to the legal weaknesses present in the institutional frameworks of these countries, which may be corrected voluntarily by internal mechanisms of good governance.

The Latin American environment differs significantly from others, in areas such as the limited quality of its formal institutions, especially those related to levels of corruption, property rights and the functioning of the judicial system (Florensa et al. 2015). All of these questions can affect the external prestige of family businesses. Moreover, this institutional environment is characterised by a historical, religious and cultural legacy based on the existence of a class and authority structure that strongly influences how family businesses are managed (Basco et al. 2015). This background is a powerful determinant of the functioning of supervisory bodies and of corporate decisions, including those related to CSR (Vázquez et al. 2020). In addition, these institutional characteristics influence the role played by women in corporate decision making. Even if their presence is relegated to the social context and they are excluded from the economic sphere, women's role in management can still be of crucial importance in creating the image of modernity and good governance that family businesses wish to transmit.

Accordingly, this study examines the situation of female board members in family firms. Our main aim is to determine whether the presence of a critical mass of female board members affects the firm's CSR practices, and if so, whether this effect differs between family and non-family businesses. In this regard, we assume that the intrinsic characteristics of women only produce a tangible effect when their equal status and legitimacy in the 
boardroom are generally acknowledged. In addition, we consider whether the Latin American institutional environment moderates the influence of female directors on firms' attitudes towards CSR strategies, which are often adopted in response to the characteristic weaknesses of the legal system in these countries.

The results obtained-from a sample of 22,958 observations, corresponding to an unbalanced data panel of 5124 companies for the period 2010-2016-emphasise the powerful impact of gender diversity on levels of sustainability of business performance. These results also highlight the existence of type I (organisational) and type II (institutional) compensation effects, which reduce or eliminate differences between family and non-family firms, whether they are located in Latin American countries or not.

This research contributes to the literature in various respects. Firstly, we propose a new theoretical framework, based on a detailed analysis of the moderating role played by organisational and institutional contexts on the impact produced by the presence of a critical mass of female directors on the company board, in relation to CSR performance. These questions are examined jointly and directly, with particular attention to the context of the family firm and the institutional environment in Latin America.

In addition, the analysis presented enhances our understanding of the relationship between boardroom diversity and CSR, complementing the limited previous research in this field (Wei et al. 2017; Cook and Glass 2018; Amorelli and García-Sánchez 2019), by associating CSR commitment with the presence of a critical mass of female directors on the company board, in comparisons of family and non-family firms. Finally, we underpin knowledge of the institutional factors that influence the above-mentioned relationship, identifying the existence of compensatory effects between certain characteristics of the family firm and the coercive and regulatory pressures exerted in Latin America.

The rest of this paper is structured as follows: Section 2 presents the theoretical framework employed and reviews the literature in this field, thus providing the basis for our study hypotheses. Section 3 describes the empirical framework of the study (model and technique of analysis, study variables and sample). In Section 4, we present and discuss the results obtained. Finally, we summarise the main conclusions drawn, set out the implications of our findings and acknowledge the study's limitations.

\section{Theoretical Framework and Research Hypotheses}

Studies have shown that a company's failure to match CSR expectations can provoke reputational and financial harm (Koh et al. 2014) and diminish the moral capital previously generated (Dögl and Behnam 2015). In addition, substantial costs may be incurred if infractions are committed against (for example) environmental or employment regulations. To avoid adverse effects on the corporate image that may be caused by irresponsible social or environmental practices, companies may invest in CSR strategies, in the view that this will avert or limit financial sanctions or reputational damage and/or provide monetary and non-monetary benefits (Orlitzky et al. 2003; Malik 2015; Wang et al. 2015; Lins et al. 2017).

The degree to which a firm's CSR strategies meet stakeholders' demands is strongly influenced by the composition of its board of directors (Birindelli et al. 2018) especially as concerns gender diversity (Cuadrado-Ballesteros et al. 2015; Setó-Pamies 2015; Valls Martínez et al. 2020). At the same time, however, the impact produced by gender diversity among the board of directors is moderated by the organisational and institutional environment in which the firm operates (Uribe-Bohorquez et al. 2019; Amorelli and García-Sánchez 2019). These questions are addressed in the following subsections.

\subsection{Female Directors and CSR}

Many studies have considered the strategic importance of female directors in the company board (Almor et al. 2019; Boutchkova et al. 2020; Kolev and McNamara 2020), referring to various organisational and psychological theories that, on the one hand, identify benefits arising from their presence but, on the other, highlight the practical difficulties that may be encountered in materialising these benefits. These conflicting questions 
underlying gender diversity in company boards might explain why companies differ in their commitment to CSR.

According to the theory of social identity, individuals make use of demographic attributes, such as gender, to classify themselves among social categories and establish their social identity in accordance with their membership of these categories (Tajfel 1982). In consequence, female company directors tend to act in accordance with the gender stereotype, according to which they are socially more sensitive, emotional and empathic than men (Boulouta 2013), contributing novel points of view and heterogeneity to the decision-making process. In the context of the business environment, the theory of resource dependence argues that differences among business leaders give rise to diversity in companies' strategic decisions, in the policies adopted, the actions performed and the results achieved (Hambrick 2007). In this context, therefore, the theory of social identity suggests that female company directors will supply different values, skills and professional experience and will be more sensitive than their male counterparts to social concerns, thus exerting a positive influence on the company's social performance (Giannarakis et al. 2014).

In view of these considerations, it can be argued that female directors make strategic decisions aimed at improving the firm's relationship with its stakeholders and at promoting ethical corporate behaviour (García-Sánchez et al. 2008). The different perspectives of male and female company directors can be of great benefit to the firm, providing it with a balanced outlook towards economic, social and environmental issues (Setó-Pamies 2015). In this respect, empirical evidence suggests there is a positive relationship between gender diversity in the boardroom and greater commitment to CSR (Fernández-Gago et al. 2016; Kassinis et al. 2016).

However, women directors are usually in the minority, in a business world that is still predominantly male. In consequence, and according to Kanter's theory of tokenism (Kanter 1977), women are faced by major barriers in expressing their opinions and for these views being taken into account. As a result, their ability to influence decision making on questions such as CSR is often severely limited (Cook and Glass 2018; Wei et al. 2017). According to the theory of critical mass, when a company decides to innovate, there must be at least three women on the board for the female perspective to be influential (Torchia et al. 2011). This conclusion has been corroborated by empirical studies of CSR strategies (Post et al. 2011; Cook and Glass 2018; DeMartini 2019; Amorelli and GarcíaSánchez 2019, 2020). In view of these considerations, we present the following hypothesis:

Hypothesis 1 (H1). Female directors can only promote CSR strategies effectively when the proportion of women on the board reaches a critical mass.

However, women's impact on decision making does not depend solely on the presence of a critical mass. It also requires an appropriate organisational and institutional environment that facilitates their contributions and fosters the perception that women are equal members of the board in every respect (Tsui et al. 2002).

\subsection{Female Directors and CSR in the Family Firm: The Moderating Effect of the Organisational Environment}

Family firms are characterised by the fact that their founders and/or family descendants are not only majority shareholders but also hold management positions and/or sit on the board of directors (Chen et al. 2008; Cuadrado-Ballesteros et al. 2015). This accumulation of responsibilities gives the family representatives great power over the company's management and its decisions (Hoffman et al. 2006), together with close involvement in day-to-day activities and unlimited access to information, which allows them much closer control over management processes and employees than is the case in non-family companies.

It has been suggested that family firms make decisions in accordance with the postulates of the socio-emotional wealth model (SEW) discussed by Wiseman and Gómez-Mejía (1998) and Gómez-Mejía et al. (2007). These authors argue that within family businesses 
a fundamental aspect of the decision-making process is the belief that SEW must be preserved. This understanding shapes the board's formulation of problems and its approach to their solution, forming the primary reference point underlying company management. When the loss of SEW is threatened, or when an opportunity to improve it is observed, family owners may prefer decisions that are not driven purely by economic logic. Indeed, the family might even be willing to put the company at risk if they deem this necessary to protect their SEW. In consequence, management decisions will be taken with a view to satisfy the interests of family owners-not necessarily financially, and possibly diverging from those of non-family investors, who might prefer returns that are quantifiable in monetary terms (Miller and Breton-Miller 2006).

Therefore, in the family firm the motivation for committing the business to sustainability is based on parameters that are not purely economic, but also reflect the priorities and functions of the family members involved (Berrone et al. 2010). According to the latter authors, the decisions taken by family directors in relation to CSR may be instrumental or normative. Instrumental motives, indirectly linked to specific financial outcomes, are those associated with the gains expected from enhancing the firm's reputation and thus helping ensure the continuity of the organisation. In this respect, investment in CSR allows the firm to accumulate reserves of goodwill that provide insurance against misadventure, bolster market confidence in the firm and enhance its image, all of which contribute to maintaining a continuing, stable flow of earnings, since even in adverse situations these factors will make stakeholders more likely to give the company the benefit of the doubt. This protection is especially attractive for family firms, whose owners often concentrate all their capital within the organisation (Górriz and Fumás 1996; Pérez-Pérez et al. 2019; Urbaníková et al. 2020). The adoption of CSR-oriented policies, thus, provides a means of ensuring the continuity of the family legacy and of strengthening and protecting the family's SEW.

The normative justifications for favouring sustainability reside in the family's wish to be considered a responsible member of society (Dyer and Whetten 2006). The company is viewed as an extension and a mirror image of the family, and therefore as reflecting the fundamental values of the family members (Chrisman et al. 2007). Family owners are usually well known in their environment and are often committed to the cause of sustainability in order to prevent selfish or short-sighted business practices from tarnishing the family name and provoking general condemnation, with emotionally devastating consequences for its members (Berrone et al. 2010). Indeed, one of the benefits of CSR policies is closely related to the question of SEW, namely the consequent strengthening of the family's reputation and image in society (Gómez-Mejía et al. 2007). Hence, reputational considerations, which are of vital importance in family businesses with an important investment in SEW, can lead these firms to emphasise their commitment to social responsibility.

These arguments are supported by extensive empirical evidence. Thus, Craig and Dibrell (2006); Berrone et al. (2010); Neubaum et al. (2012); Sharma and Sharma (2011) and Dangelico et al. (2019) all conclude that family-controlled businesses are more likely than non-family firms to perform environmentally sustainable practices. Similarly, Stavrou et al. (2007) and Cruz et al. (2010) have reported that the employees of family firms enjoy greater job stability and better working conditions, while Cuadrado-Ballesteros et al. (2017) and Gavana et al. (2019) highlight these firms' greater commitment to philanthropic activities and ethical issues. Dyer and Whetten (2006) and Bingham et al. (2011) supply preliminary evidence that the activities of family businesses are significantly less harmful, socially and environmentally, and other studies have reported that family firms present a greater predisposition towards CSR (Chrisman et al. 2007; Dyer and Whetten 2006; Cennamo et al. 2012; Campopiano and De Massis 2015; García-Sánchez et al. 2020c). Finally, these firms are characterised by qualities such as ethical commitment ( $\mathrm{O}^{\prime}$ Boyle et al. 2010; Kidwell et al. 2012), benevolence (Hauswald and Hack 2013) and integrity, empathy, warmth, courage, awareness and zeal (Payne et al. 2011) among other emotional intelligence characteristics (Minárová et al. 2020). 
Within the family business, the immaterial feminine attributes of meticulousness, loyalty, flexibility, patience and attention that are commonly attributed to female members of the board constitute an important asset and are highly valued in the management of family businesses, which are characterised by their informal operation, based on family ties (Rigby and Sanchís 2006; Kuschel 2019). In addition to the traditional functions performed within the board, female directors of family firms often act as emotional referents, with the gender roles prevailing among the family owners being carried over to the business environment, thus maintaining the family's balance and emotional harmony and transmitting its values, which are closely bound to the firm's SEW.

In view of these considerations of CSR and the role of gender diversity in the family business, we suggest that the existence of a critical mass of women on the board of directors would give rise to a stronger commitment to CSR by family firms than by non-family organisations. Accordingly, we propose the following hypothesis regarding the existence of a leverage effect:

Hypothesis 2 (H2). When the proportion of women on the board of directors of a family firm reaches a critical mass, their impact on its CSR strategies is intensified.

\subsection{The Moderating Effect of the Latin American Institutional Environment}

Various studies have considered the influence of the commercial environment on business sustainability. According to institutional theory, organisations operating in similar contexts will adopt homogeneous forms of business behaviour, in order to ensure their institutional legitimisation, which is a key factor in a firm's survival. Business convergence is the outcome of a corporate decision to resemble others (mimetic isomorphism), to do what is considered professionally appropriate (normative isomorphism) and to comply with applicable rules and regulations (coercive isomorphism) (Pérez-Batres et al. 2011). In the present study, we consider the moderating effect of the institutional environment in Latin America, where coercive characteristics may weaken the business fabric (Gómez-Mejía et al. 2020), in comparison with Anglo-Saxon, European and Asian countries (Berrone et al. 2020; García-Sánchez 2020a).

According to institutional theory, the moderating role of the Latin American business environment is determined by two factors: firstly, by the institutions, which determine the rules of play, both formal and informal, for a society or environment and the interactions within it (North 1990); and on the other hand, by the concept of isomorphism, regarding the acceptance of and adaptation to these social norms. Thus, organisational action is shaped and, over time, legitimised within the environment (Young et al. 2000). At the economic level, this theory holds that companies operate within institutional contexts that affect their actions and expectations. In other words, different organisations operating in a given environment will behave in similar ways, to maximise their compatibility and legitimacy, thus presenting isomorphism (DiMaggio and Powell 1983; García-Sánchez et al. 2016).

Environmental differences arise from variations in history, culture, politics, legal systems, standards, traditions and other country-specific circumstances, which transcend the individual natures of companies and their boards of directors (Denis and McConnell 2003). In consequence, some control mechanisms are more effective in certain environments than in others. Latin America presents an ideal scenario for an investigation of the type we propose, since it is characterised as offering weak protection for minority shareholders. In this situation, in the absence of a strong legal system, family businesses can act as a substitute (de Holan and Sanz 2006), in which the boards of directors promote policies of good governance in line with those observed elsewhere, such as the Anglo-Saxon countries (Briano-Turrent and Poletti-Hughes 2017).

The forms of internal and external governance associated with a given legal system could be substitutional or complementary. In Latin America, many large companies adopt a substitutive approach in their mechanisms of internal corporate governance, seeking to offset the weaknesses of the institutional legal system (Poletti-Hughes and Martínez-Garcia 2020). 
Among family firms, this approach is reinforced by the presence of family owners, who exercise management and control functions that not only compensate for the lack of legal protection but also limit the exercise of managerial discretion (Cuadrado-Ballesteros et al. 2015). The owners' presence, thus, is associated with the defence of their own interests, which in terms of CSR means that the firm will make a greater commitment to business sustainability.

We suggest that the advantages associated with the presence of a critical mass of female directors on the board, as discussed in Section 2.1, are positively moderated by the business context prevailing in Latin America, because the existence of coercive pressures encourages Latin American companies, many of which are family businesses, to employ governance mechanisms that overcome the weaknesses of their countries' legal systems. This circumstance, extrapolated to the field of sustainability, suggests that family firms will present a stronger commitment to CSR than their non-family counterparts. In this regard, we propose the final study hypothesis:

Hypothesis 3 (H3). In Latin America, the role played by female directors in the firm's adoption of CSR strategies is intensified when the proportion of women on the board of directors reaches a critical mass.

\section{Method}

3.1. Sample

Our analysis was based on 22,958 observations, obtained from an unbalanced data panel of 5124 companies for the period 2010-2016. In this sample, 1093 of the companies (7398 observations) were family firms. This sample was extracted from the Thomson Reuters international database, and the information available was applied in Equation (1).

Although corporate information was available for 2019, in order to use a data panel that is homogeneous over time, the 2016 data were the last ones considered. This is because for 2017 and subsequent years, the sample of family firms is less representative and their inclusion might bias our analysis. In addition, the presence in the database of companies from several countries differs in the most recent years with respect to the earlier ones.

The data distribution was homogeneous throughout the study period. Geographically, however, there was a bias towards companies located in the USA. By areas of activity, those with the greatest weight were the Industrial and the Financial/Real Estate sectors. These biases were methodologically corrected by the inclusion of country and sector control variables. Of all the firms included in the sample, 919 were located in Latin America.

\subsection{Model and Analysis}

In accordance with the study hypotheses, we analysed the relation between the existence of a critical mass of female directors and the firm's commitment to CSR. We also examined the moderating role of the organisational environment typical of family businesses and that of the institutional pressures present in Latin America. These hypotheses were tested by reference to Equation (1), which summarises an empirical model in which CSR performance is explained by the presence of a critical mass of female directors on the board and by its interaction with the moderating variables related to the family firm and its country of origin. In addition, various control variables were included, in order to exclude bias from the results obtained. The model incorporated a specific company effect, $\eta$, to represent the unobservable heterogeneity that affects the company's decision-making processes, and $\mu$, which represents the perturbation. The company is identified by $i$, and the time period by $t$. The parameter to be estimated is $\varphi$. Thus:

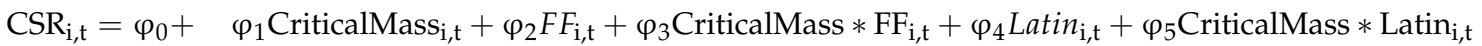

$$
\begin{aligned}
& +\varphi_{6} F F * \operatorname{Latin}_{\mathrm{i}, \mathrm{t}}+\varphi_{7} \text { CriticalMass } * \text { FF } * \text { Latin }_{\mathrm{i}, \mathrm{t}}+\varphi_{8} \text { Size }_{\mathrm{i}, \mathrm{t}}+\varphi_{9} \Delta \text { Sales }_{\mathrm{i}, \mathrm{t}}+\varphi_{10} \mathrm{ROA}_{\mathrm{i}, \mathrm{t}} \\
& +\varphi_{11} \text { Leverage }_{i, t}+\varphi_{12} \mathrm{CFO}_{\mathrm{i}, \mathrm{t}}+\varphi_{13} \text { Dividend }_{\mathrm{i}, \mathrm{t}}+\varphi_{14} \text { BoardSize }_{\mathrm{i}, \mathrm{t}}+\varphi_{15} \text { BoardActivity }_{\mathrm{i}, \mathrm{t}} \\
& +\varphi_{16} \text { BoardIndep }_{\mathrm{i}, \mathrm{t}}+\varphi_{17} \text { Duality }_{\mathrm{i}, \mathrm{t}}+\varphi_{18} \text { CSR_committee }_{\mathrm{i}, \mathrm{t}}+\varphi_{19} \text { ICSRPI }_{\mathrm{i}, \mathrm{t}}+\varphi_{20} \text { NCSRPI }_{\mathrm{i}, \mathrm{t}} \\
& +\varphi_{21} \text { Industry }_{\mathrm{i}, \mathrm{t}}+\varphi_{22} \text { Country }_{\mathrm{i}}+\varphi_{23} \text { Year }_{\mathrm{t}}+\mu_{\mathrm{it}}+\eta_{\mathrm{i}}
\end{aligned}
$$


For the model-dependent variable, "CSR" is represented by the Thomson Reuters ES_Score (Garcia et al. 2017) which measures the company's performance in environmental and social terms in the absence of bias (Amor-Esteban et al. 2020). To ensure the robustness of the results obtained, and following Garcia et al. (2017), this variable was subdivided into three dimensions: environmental "ENV", social "SOCIAL" and good governance "GOV". For the environmental factors, the data included information on energy used, water recycled, carbon emissions, waste recycled and episodes of spills and other forms of pollution. The data for the social factor included employee turnover, injury rate, accidents, training hours, employment of women, donations, and health and safety disputes. Good governance refers mainly to the existence of transparency towards investors, codes of ethics and good governance.

Following Torchia et al. (2011), the independent variable "CriticalMass" was represented by a dummy variable that took the value 1 if there are at least three women on the board of directors, and 0 otherwise.

The moderating variables, "FF" and "Latin" were dummy variables that took the value 1 if the company is a family firm or if its country of origin is in Latin America, respectively: otherwise, they took the value 0 . Although the definition of a family firm is not unanimously accepted, following Cascino et al. (2010); Berrone et al. (2012) and Singla, Veliyath and George (Singla et al. 2014), we applied the criterion of ownership, control and management. Accordingly, we considered a family business to be one in which the majority shareholder is a family or family group, with more than $20 \%$ of the votes and where at least one member of this controlling family occupies a management position or sits on the board of directors. The interaction of the variable "CriticalMass" with "FF" and "Latin" revealed the existence or otherwise of organisational and institutional moderating effects, respectively.

Finally, various control variables were included to reduce or eliminate bias from the results obtained (Bear et al. 2010; Chapple and Truong 2015; Bansal et al. 2018; García-Sánchez 2020b). These variables referred to the company, the board of directors and the environment. The following business characteristics were included as controls: "Size", which represents the size of the company as the natural logarithm of its assets ${ }^{1}$ (Terrón-Ibáñez et al. 2019); " $\Delta$ Sales", the variation of sales since the period $t-1$; "ROA", the firm's profitability expressed by the return obtained as a proportion of company assets; "Leverage", the relationship between the company's borrowing and its own resources; "CFO", the standard deviation of the value of operational cash flow since the period $t-2$; and "Dividend", the total dividends paid per share. The factors representative of the board of directors were "BoardSize", measured by the total number of directors (Michelon and Parbonetti 2012); "BoardActivity", measured by the number of meetings held each year (García-Sánchez et al. 2013); and "BoardIndep", the proportion of independent directors on the board. In line with Cuadrado-Ballesteros et al. (2015) and Briano-Turrent and PolettiHughes (2017), this parameter was calculated as the percentage of independent directors with respect to the total number of directors. "Duality" was a dummy variable that takes the value 1 for companies whose CEO is also the chairman of the board of directors, and the value 0 otherwise. Finally, "CSR_committee" was a dummy variable that takes the value 1 if the company has a CSR committee, and the value 0 if it does not.

To identify individually and in more detail the effect of institutional pressure on CSR, by country and by sector, we included the ICSRPI and NCSRPI indexes proposed by Amor-Esteban et al. (2018a, 2019). Finally, the results were also controlled by country, sector and year. Thus, Country, Industry and Year were numerical variables that identify the firm's country of origin, a concept that is associated with that of national identity (Amor-Esteban et al. 2018c), its activity sector and the operational year analysed, respectively.

1 In this respect, various measures have been proposed, but none reflect all the characteristics of firm size. All present advantages and disadvantages. The proxy in question was selected because it measures total firm resources (Dang et al. 2018). 
The proposed econometric model was based on panel data dependence techniques. This method improves the capacity and explanatory power of the model by extending the time period analysed, in addition to improving consistency, controlling for unobservable heterogeneity and improving parameter estimation (for example, by offering more informative data, with less collinearity among the variables). In this case, the problem of unobservable heterogeneity can be controlled by the company effect $\eta$, thus reducing the problem to that of considering board members' characteristics ( $\mathrm{Li}$ 2018) or the corporate visibility ( $\mathrm{Li}$ et al. 2019) not included in the model. The analysis technique used to estimate Equation (1) was that of a tobit regression for panel data, since the dependent variable CSR is censored. A lag period was used for the independent and control variables in order to control for possible endogeneity.

\section{Results}

\subsection{Descriptive Results}

Table 1 shows the descriptive statistics obtained. The companies analysed had a CSR score of around $50 \%$, with values that were strongly homogeneous in all three dimensions considered. On average, the company board was composed of 10 directors, of whom 51\% were independent. A CSR committee had been established by $42.50 \%$ of the firms. Potential conflicts of independence were observed in $61 \%$, where the CEO was also the chairman of the board of directors. In $57 \%$ of cases, the board included a critical mass of three or more female directors.

Table 1. Descriptive statistics.

\begin{tabular}{|c|c|c|}
\hline Variable & Mean & Std. Dev. \\
\hline CSR & 49.838 & 30.971 \\
\hline ENV & 49.589 & 31.127 \\
\hline SOCIAL & 49.066 & 31.849 \\
\hline GOV & 51.034 & 30.150 \\
\hline Size & 15.738 & 3.018 \\
\hline$\Delta$ Sales & 22.854 & 275.424 \\
\hline ROA & 4.274 & 86.159 \\
\hline Leverage & 2.010 & 8.340 \\
\hline $\mathrm{CFO}$ & 0.011 & 0.010 \\
\hline Dividend & 45.767 & 61.356 \\
\hline BoardSize & 10.242 & 3.655 \\
\hline BoardActivity & 18.082 & 10.982 \\
\hline BoardIndep & 51.393 & 30.187 \\
\hline ICSRPI & 0.039 & 3.016 \\
\hline NCSRPI & 0.324 & 8.799 \\
\hline \multirow{4}{*}{\multicolumn{2}{|c|}{$\begin{array}{c}\text { CriticalMass } \\
\text { Duality }\end{array}$}} & $\%$ \\
\hline & & 27.170 \\
\hline & & 60.80 \\
\hline & & 42.50 \\
\hline
\end{tabular}

$n=22,958$ observations -5124 firms for the period 2010-2016.

As can be seen in Table 2, the bivariate correlations between the study variables are not strong, and so there are unlikely to be problems of multicollinearity. 
Table 2. Bivariate correlations.

\begin{tabular}{|c|c|c|c|c|c|c|c|c|}
\hline & & 1 & 2 & 3 & 4 & 5 & 6 & 7 \\
\hline 1 & CSR & 1.000 & & & & & & \\
\hline 2 & SOCIAL & $0.907^{* * *}$ & & & & & & \\
\hline 3 & ENV & $0.832 * * *$ & $0.803^{* * *}$ & 1.000 & & & & \\
\hline 4 & GOV & $0.570 * * *$ & $0.341 * * *$ & $0.217 * * *$ & 1.000 & & & \\
\hline 5 & CriticalMass & $0.208^{* * *}$ & $0.197^{* * *}$ & $0.173 * * *$ & $0.141^{* * *}$ & 1.000 & & \\
\hline 6 & FF & $0.017^{* * *}$ & $0.052^{* * *}$ & $0.037^{* * *}$ & $-0.075^{* *}$ & $-0.023 * * *$ & 1.000 & \\
\hline 7 & $\mathrm{CM}^{*} \mathrm{FF}$ & $0.093 * * *$ & $0.095 * * *$ & $0.084^{* * *}$ & $0.039^{* * *}$ & $0.276^{* * *}$ & $0.707 * * *$ & 1.000 \\
\hline 8 & Latin & -0.003 & $0.027 * * *$ & 0.002 & $-0.059^{* *}$ & $0.018^{* * *}$ & $0.087 * * *$ & $0.069 * * *$ \\
\hline 9 & $\mathrm{CM}^{*}$ Latin & $0.032^{* * *}$ & $0.036^{* * *}$ & $0.029^{* * *}$ & 0.008 * & $0.136 * * *$ & $0.060^{* *}$ & $0.119 * * *$ \\
\hline 10 & FF*Latin & 0.004 & $0.031^{* * *}$ & 0.007 & $-0.047^{* * *}$ & 0.001 & $0.255^{* * *}$ & $0.193^{* * *}$ \\
\hline 11 & $\mathrm{CM}^{*} \mathrm{FF}^{*}$ Latin & $0.012 * *$ & $0.012 * * *$ & $0.009 * *$ & 0.002 & $0.075^{* * *}$ & $0.193 * * *$ & $0.273 * * *$ \\
\hline 12 & Size & $0.048^{* * *}$ & $0.103^{* * *}$ & $0.151 * * *$ & $-0.212 * * *$ & $-0.130 * * *$ & $0.194 * * *$ & $0.120 * * *$ \\
\hline 13 & $\Delta$ Sales & 0.006 & $0.008^{*}$ & $0.008 *$ & $-0.008 *$ & 0.004 & -0.001 & 0.001 \\
\hline 14 & ROA & $0.014^{* * *}$ & $0.011^{* *}$ & 0.006 & 0.000 & -0.001 & $0.011^{* * *}$ & $0.009^{* * *}$ \\
\hline 15 & Leverage & -0.004 & -0.004 & -0.007 & 0.001 & -0.001 & 0.001 & 0.002 \\
\hline 16 & $\mathrm{CFO}$ & 0.000 & $0.012 * *$ & $0.016^{* * *}$ & $-0.045^{* * *}$ & $-0.017^{* * *}$ & $0.008^{* *}$ & 0.002 \\
\hline 17 & Dividend & $-0.022 * * *$ & $-0.014^{* * *}$ & 0.007 & $-0.067^{* * *}$ & $-0.011 * * *$ & $0.021 * * *$ & $0.015^{* *}$ \\
\hline 18 & BoardSize & $0.242^{* * *}$ & $0.275^{* * *}$ & $0.275^{* * *}$ & $-0.015^{* * *}$ & $0.285^{* * *}$ & $0.039^{* * *}$ & $0.142 * * *$ \\
\hline 19 & BoardActivity & $0.107^{* * *}$ & $0.138^{* * *}$ & $0.138^{* * *}$ & $-0.042^{* * *}$ & $0.013^{* *}$ & $0.059^{* * *}$ & $0.026^{* * *}$ \\
\hline 20 & BoardIndep & $0.156^{* * *}$ & $-0.011^{* *}$ & $-0.077^{* * *}$ & $0.596^{* * *}$ & $0.062^{* * *}$ & -0.112 *** & $-0.024^{* * *}$ \\
\hline 21 & Duality & -0.003 & $0.036^{* * *}$ & $0.018^{* * *}$ & $-0.074^{* * *}$ & $0.012 * * *$ & $0.051^{* * *}$ & $0.024^{* * *}$ \\
\hline 22 & CSRCommittee & $0.551^{* * *}$ & $0.543^{* * *}$ & $0.564^{* *}$ & $0.249^{* * *}$ & $0.141^{* * *}$ & $0.025^{* * *}$ & $0.070^{* * *}$ \\
\hline 23 & ICSRPI & $0.058^{* * *}$ & $0.063^{* * *}$ & $0.087^{* * *}$ & $0.012^{* *}$ & $-0.018 * * *$ & $0.037 * * *$ & $0.023^{* * *}$ \\
\hline \multirow[t]{2}{*}{24} & NCSRPI & $0.076^{* * *}$ & $0.097^{* * *}$ & $0.101^{* * *}$ & $-0.019^{* * *}$ & $-0.066^{* * *}$ & $0.108^{* * *}$ & $0.066^{* * *}$ \\
\hline & & 8 & 9 & 10 & 11 & 12 & 13 & 14 \\
\hline 8 & Latin & 1.000 & & & & & & \\
\hline 9 & $\mathrm{CM}^{*}$ Latin & $0.778^{* * *}$ & 1.000 & & & & & \\
\hline 10 & FF*Latin & $0.567^{* * *}$ & $0.414^{* * *}$ & 1.000 & & & & \\
\hline 11 & $\mathrm{CM}^{*} \mathrm{FF}^{*}$ Latin & $0.430 * * *$ & $0.553^{* * *}$ & $0.758^{* * *}$ & 1.000 & & & \\
\hline 12 & Size & $0.114^{* * *}$ & $0.077^{* * *}$ & $0.095^{* * *}$ & $0.067^{* * *}$ & 1.000 & & \\
\hline 13 & $\Delta$ Sales & -0.001 & -0.001 & -0.001 & 0.000 & $0.007^{* *}$ & 1.000 & \\
\hline 14 & ROA & $0.008^{* *}$ & $0.008^{* *}$ & 0.005 & 0.006 * & $0.026^{* * *}$ & 0.001 & 1.000 \\
\hline 15 & Leverage & 0.000 & 0.000 & 0.000 & 0.000 & -0.003 & 0.000 & 0.000 \\
\hline 16 & $\mathrm{CFO}$ & $0.008^{* *}$ & 0.003 & 0.005 & 0.002 & $0.075^{* * *}$ & 0.001 & 0.003 \\
\hline 17 & Dividend & -0.003 & -0.003 & -0.001 & -0.001 & $0.144^{* * *}$ & 0.001 & 0.002 \\
\hline 18 & BoardSize & $0.031^{* * *}$ & $0.057^{* * *}$ & $0.021^{* * *}$ & $0.036^{* *}$ & $0.162^{* * *}$ & 0.003 & 0.008 \\
\hline 19 & BoardActivity & 0.005 & 0.004 & -0.003 & $-0.010 *$ & $0.037^{* * *}$ & 0.004 & $-0.010 *$ \\
\hline 20 & BoardIndep & $-0.064^{* * *}$ & -0.006 & $-0.049^{* * *}$ & -0.006 & $-0.183 * * *$ & -0.002 & -0.006 \\
\hline 21 & Duality & $0.022 * * *$ & 0.006 & $0.013^{* * *}$ & $0.010 * *$ & 0.001 & 0.000 & -0.008 \\
\hline 22 & CSRCommittee & 0.016 *** & $0.030 * * *$ & $0.008 *$ & $0.014^{* * *}$ & $0.100^{* * *}$ & -0.002 & -0.005 \\
\hline 23 & ICSRPI & $0.048^{* * *}$ & $0.040^{* * *}$ & $0.033 * *$ & $0.025^{* * *}$ & $-0.065 * * *$ & 0.002 & 0.000 \\
\hline \multirow[t]{2}{*}{24} & NCSRPI & $-0.013^{* * *}$ & $-0.008 *$ & $-0.020 * * *$ & $-0.015^{* * *}$ & $-0.015^{* * *}$ & 0.001 & $0.011^{* *}$ \\
\hline & & 15 & 16 & 17 & 18 & 19 & 20 & 21 \\
\hline 15 & Leverage & 1.000 & & & & & & \\
\hline 16 & $\mathrm{CFO}$ & 0.000 & 1.000 & & & & & \\
\hline 17 & Dividend & 0.000 & $0.122 * * *$ & 1.000 & & & & \\
\hline 18 & BoardSize & 0.002 & -0.002 & $-0.021^{* * *}$ & 1.000 & & & \\
\hline 19 & BoardActivity & -0.005 & 0.005 & 0.007 & $-0.118^{* * *}$ & 1.000 & & \\
\hline 20 & BoardIndep & 0.005 & $-0.017^{* * *}$ & $-0.035^{* * *}$ & $-0.134^{* * *}$ & $-0.285^{* * *}$ & 1.000 & \\
\hline 21 & Duality & -0.004 & $0.012 * *$ & 0.006 & $-0.063^{* * *}$ & $0.297^{* * *}$ & $-0.161^{* * *}$ & 1.000 \\
\hline 22 & CSRCommittee & -0.005 & $0.014^{* * *}$ & -0.002 & $0.155^{* *}$ & $0.180^{* * *}$ & $-0.011^{* *}$ & $0.053^{* * *}$ \\
\hline 23 & ICSRPI & -0.003 & $0.018^{* * *}$ & $-0.011 * * *$ & $-0.033^{* * *}$ & $0.042^{* * *}$ & $-0.009 * *$ & -0.009 ** \\
\hline \multirow[t]{2}{*}{24} & NCSRPI & $0.006^{*}$ & $-0.015^{* * *}$ & $0.019^{* * *}$ & $-0.036^{* *}$ & $0.220^{* * *}$ & $-0.104^{* * *}$ & $0.134^{* * *}$ \\
\hline & & 22 & 23 & 24 & & & & \\
\hline 22 & CSRCommittee & 1.000 & & & & & & \\
\hline 23 & ICSRPI & $0.053^{* * *}$ & 1.000 & & & & & \\
\hline 24 & NCSRPI & $0.054^{* * *}$ & $0.039 * * *$ & 1.000 & & & & \\
\hline
\end{tabular}

\subsection{Basic Models}

Table 3 shows the results for Equation (1), using as dependent variables the CSR performance recorded and its social, environmental and good governance dimensions. 
Table 3. Results obtained for the hypothesis test models.

\begin{tabular}{|c|c|c|c|c|}
\hline & CSR & SOCIAL & ENV & GOV \\
\hline & $\begin{array}{c}\text { Coeff. } \\
\text { (Std.Error) }\end{array}$ & $\begin{array}{c}\text { Coeff. } \\
\text { (Std.Error) }\end{array}$ & $\begin{array}{c}\text { Coeff. } \\
\text { (Std.Error) }\end{array}$ & $\begin{array}{c}\text { Coeff. } \\
\text { (Std.Error) }\end{array}$ \\
\hline CriticalMass & $\begin{array}{c}6.359^{* * *} \\
(0.542)\end{array}$ & $\begin{array}{c}6.872^{* * *} \\
(0.547)\end{array}$ & $\begin{array}{c}6.343^{* * *} \\
(0.550)\end{array}$ & $\begin{array}{c}3.586^{* * *} \\
(0.466)\end{array}$ \\
\hline FF & $\begin{array}{l}0.0714 \\
(0.661)\end{array}$ & $\begin{array}{c}0.970 \\
(0.679)\end{array}$ & $\begin{array}{c}0.405 \\
(0.700)\end{array}$ & $\begin{array}{l}-1.678^{* * *} \\
(0.587)\end{array}$ \\
\hline CriticalMass*FF & $\begin{array}{l}0.0476 \\
-1.157\end{array}$ & $\begin{array}{l}-1.466 \\
-1.167\end{array}$ & $\begin{array}{l}-0.604 \\
-1.174\end{array}$ & $\begin{array}{l}2.019^{* *} \\
(0.995)\end{array}$ \\
\hline Latin & $\begin{array}{l}0.000 \\
0.001\end{array}$ & $\begin{array}{l}0.000 \\
0.001\end{array}$ & $\begin{array}{l}0.000 \\
0.001\end{array}$ & $\begin{array}{l}0.000 \\
0.001\end{array}$ \\
\hline CriticalMass*Latin & $\begin{array}{c}2.327 \\
-3.030\end{array}$ & $\begin{array}{c}3.931 \\
-3.065\end{array}$ & $\begin{array}{c}1.439 \\
-3.093\end{array}$ & $\begin{array}{c}0.409 \\
-2.618\end{array}$ \\
\hline FF*Latin & $\begin{array}{c}1.247 \\
-2.597\end{array}$ & $\begin{array}{c}0.496 \\
-2.661\end{array}$ & $\begin{array}{c}1.265 \\
-2.734\end{array}$ & $\begin{array}{c}3.756 \\
-2.296\end{array}$ \\
\hline CriticalMass*FF*Latin & $\begin{array}{l}-7.977 \\
-6.933\end{array}$ & $\begin{array}{l}-13.64 * \\
-6.995\end{array}$ & $\begin{array}{l}-13.77^{*} \\
-7.032\end{array}$ & $\begin{array}{l}-6.612 \\
-5.962\end{array}$ \\
\hline Size & $\begin{array}{l}0.678^{* * *} \\
(0.0945)\end{array}$ & $\begin{array}{l}0.756^{* * *} \\
(0.0968)\end{array}$ & $\begin{array}{l}0.891^{* * *} \\
(0.0994)\end{array}$ & $\begin{array}{l}-0.287^{* * *} \\
(0.0835)\end{array}$ \\
\hline$\Delta$ Sales & $\begin{array}{l}0.000114 \\
(0.00132)\end{array}$ & $\begin{array}{l}0.000220 \\
(0.00132)\end{array}$ & $\begin{array}{c}-0.000649 \\
(0.00133)\end{array}$ & $\begin{array}{l}0.000460 \\
(0.00113)\end{array}$ \\
\hline ROA & $\begin{array}{c}0.0128 \\
(0.00838)\end{array}$ & $\begin{array}{c}0.00134 \\
(0.00847)\end{array}$ & $\begin{array}{l}-0.00509 \\
(0.00853)\end{array}$ & $\begin{array}{c}0.00566 \\
(0.00723)\end{array}$ \\
\hline Leverage & $\begin{array}{c}4.21 \times 10^{-5} \\
(0.000116)\end{array}$ & $\begin{array}{c}1.91 \times 10^{-5} \\
(0.000117)\end{array}$ & $\begin{array}{c}8.73 \times 10^{-5} \\
(0.000117)\end{array}$ & $\begin{array}{c}1.96 \times 10^{-5} \\
\left(9.93 \times 10^{-5}\right)\end{array}$ \\
\hline $\mathrm{CFO}$ & $\begin{array}{l}-1.76 \times 10^{-10} \\
\left(1.96 \times 10^{-10}\right)\end{array}$ & $\begin{array}{c}8.67 \times 10^{-11} \\
\left(1.99 \times 10^{-10}\right)\end{array}$ & $\begin{array}{l}-1.20 \times 10^{-10} \\
\left(2.02 \times 10^{-10}\right)\end{array}$ & $\begin{array}{c}-3.36 \times 10^{-10} * * \\
\left(1.71 \times 10^{-10}\right)\end{array}$ \\
\hline Dividend & $\begin{array}{c}3.45 \times 10^{-5} \\
(0.000752)\end{array}$ & $\begin{array}{c}0.000245 \\
(0.000768)\end{array}$ & $\begin{array}{c}0.000834 \\
(0.000786)\end{array}$ & $\begin{array}{c}-0.00183 * * * \\
(0.000661)\end{array}$ \\
\hline BoardSize & $\begin{array}{l}1.828 * * * \\
(0.0580)\end{array}$ & $\begin{array}{l}2.007^{* * *} \\
(0.0586)\end{array}$ & $\begin{array}{l}1.858^{* * *} \\
(0.0590)\end{array}$ & $\begin{array}{c}0.0660 \\
(0.0500)\end{array}$ \\
\hline BoardActivity & $\begin{array}{l}0.187^{* * *} \\
(0.0161)\end{array}$ & $\begin{array}{l}0.181^{* * *} \\
(0.0162)\end{array}$ & $\begin{array}{l}0.171^{* * *} \\
(0.0163)\end{array}$ & $\begin{array}{l}0.0621^{* * *} \\
(0.0138)\end{array}$ \\
\hline BoardIndep & $\begin{array}{l}0.131^{* * *} \\
(0.00653)\end{array}$ & $\begin{array}{l}-0.00696 \\
(0.00660)\end{array}$ & $\begin{array}{l}-0.0139 * * \\
(0.00664)\end{array}$ & $\begin{array}{l}0.399^{* * *} \\
(0.00564)\end{array}$ \\
\hline Duality & $\begin{array}{l}-0.184 \\
(0.341)\end{array}$ & $\begin{array}{l}0.919^{* * *} \\
(0.345)\end{array}$ & $\begin{array}{l}-0.525 \\
(0.347)\end{array}$ & $\begin{array}{l}-0.270 \\
(0.294)\end{array}$ \\
\hline CSRCommittee & $\begin{array}{c}29.46^{* * *} \\
(0.335)\end{array}$ & $\begin{array}{c}27.83^{* * * *} \\
(0.338)\end{array}$ & $\begin{array}{c}30.44^{* * *} \\
(0.340)\end{array}$ & $\begin{array}{c}15.74^{* * *} \\
(0.288)\end{array}$ \\
\hline ICSRPI & $\begin{array}{c}0.416^{* * *} \\
(0.104)\end{array}$ & $\begin{array}{l}0.329 * * * \\
(0.106)\end{array}$ & $\begin{array}{c}0.656^{* * *} \\
(0.110)\end{array}$ & $\begin{array}{c}0.149 \\
(0.0921)\end{array}$ \\
\hline NCSRPI & $\begin{array}{l}0.264^{* * *} \\
(0.0274)\end{array}$ & $\begin{array}{l}0.284^{* * *} \\
(0.0281)\end{array}$ & $\begin{array}{c}0.234^{* * *} \\
(0.0290)\end{array}$ & $\begin{array}{l}0.139 * * * \\
(0.0243)\end{array}$ \\
\hline \multicolumn{5}{|c|}{ Controlled by industry, country and year } \\
\hline Constant & $\begin{array}{c}693.2 * * * \\
(88.79)\end{array}$ & $\begin{array}{c}445.3^{* * *} \\
(89.34)\end{array}$ & $\begin{array}{c}101.8 \\
(89.75)\end{array}$ & $\begin{array}{c}1236^{* * *} \\
(76.26)\end{array}$ \\
\hline $\begin{array}{c}\text { Rho } \\
\text { Log Likelihood }\end{array}$ & $\begin{array}{c}0.2659 \\
-103,801.05^{* * *}\end{array}$ & $\begin{array}{c}0.2801 \\
-104,026.86^{* * *}\end{array}$ & $\begin{array}{c}0.3006 \\
-104,183.3^{* * *}\end{array}$ & $\begin{array}{c}0.2917 \\
-100,377.07\end{array}$ **** \\
\hline
\end{tabular}

$n=22,958$ observations corresponding to 5124 companies for the period $2010-2016 .{ }^{* * *} p<0.01,{ }^{* *} p<0.05$, $* p<0.1$.

The "CriticalMass" variable has a positive effect, statistically significant at the 99\% confidence level, in all models, which confirms hypothesis H1 regarding the influence of critical mass on sustainable business performance. This finding corroborates previous empirical evidence reported by Wei et al. (2017), Cook and Glass (2018) and Amorelli and García-Sánchez (2019).

Regarding hypothesis $\mathrm{H} 2$, on the possible influence of the family as a factor enhancing the role of women in decision making on CSR strategies, with the exception of the model 
obtained for the dependent variable "GOV", we find that "CriticalMass*FF" is not relevant from an econometric standpoint. Accordingly, this hypothesis is rejected. These results might be explained by the fact that the family firm, in terms of boardroom diversity, may not be the optimal environment for the contributions of female directors and this understanding may limit perceptions that women are, in fact, full and equal members of the board. Thus, while research has shown that women are motivated by commitment, loyalty and family values, which would seem to make them especially suitable to occupy positions of responsibility within the company (Rodríguez Zapatero and Rodríguez Jiménez 2011), our study results show, in fact, that women are more likely to be present in the management bodies of family firms than in non-family firms. This is assumed to be the consequence of the internal recruitment processes commonly employed to fill vacancies in family businesses, which facilitate the promotion of women to more senior positions.

Furthermore, studies by Sharma (2004), Ceja (2018) and Sharma and Nordqvist (2008) have highlighted the difficulties encountered by women in joining the family business, in developing a professional career and in achieving recognition of their work. Such difficulties may arise from gender stereotypes such as doubts about their capacity for long-term commitment, or from the existence of a culture oriented towards the protection of women by men, among other preconceptions. In addition, the performance of women in the family business and their competence to occupy positions of responsibility in its management are associated with aspects such as sociability, observation, emotional capital and, in general, the deployment of social skills to facilitate performance. However, these qualities are not directly related to the achievement of objectives, which is a role traditionally associated with men (Rigby and Sanchís 2006). As a result, women's opinions might be less readily accepted.

Among the different hypotheses proposed regarding CSR and the role of gender diversity in the family firm, we take the view that due to a type I (organisational) compensation effect, empirical evidence does not reveal behavioural differences between companies solely from their organisational characteristics. This compensation effect would be associated with the fact that, in relation to CSR, female directors on the board of a family business may play a secondary role that distracts attention from (or reduces the credence given to) their opinions. On the other hand, any decrease in the effect produced by their critical mass may be corrected by the importance of CSR to the SEW of family companies, which encourages them to implement more sustainable business practices.

Special mention should be made of the model estimated for the "GOV" variable, which shows that family businesses tend to present negative attitudes towards practices of good governance (FF: coeff. $=-1.678$; $p$-value $=0.004$ ), except in companies that have three or more female directors on the board (CriticalMass ${ }^{*} \mathrm{FF}$ : coeff. $=2.019 ; p$-value $=0.043$ ).

Taken together, these results suggest that the positive impact made on social and environmental performance by the presence of a critical mass of female members on the board of directors is common to all types of companies. On the other hand, as regards the dimension of good governance, we identify a moderating role by the organisational environment, related to the particularities of the family firm, noting that the promotion of values such as ethics and transparency, fostered by the existence of boardroom diversity, is greater within family businesses. The results, therefore, suggest that the presence of women on the boards of family businesses encourages the adoption of CSR practices that correct the prevalence of attention to internal SEW (family control of management and executive positions) vs. the external dimension (improving the company's image and reputation presented to its minority investors and other stakeholders).

Hypothesis H3 is tested by analysing the coefficients and the significance of the variables "CriticalMass*Latin" and "CriticalMass*FF*Latin". The effect of the first interaction is not significant in econometric terms in any of the models. This result is partially extensible to the second interaction, for which the effect is only statistically significant for the "SOCIAL" and "ENV" dimensions, at a level of confidence of $90 \%$, which is considered by many authors to be insufficient. Accordingly, we reject hypothesis $\mathrm{H} 3$, regarding the exis- 
tence of an enhancer effect of the Latin American environment derived from substitutive relations between internal mechanisms of corporate governance and the legal system.

One of the factors that could account for our study results is that of the normative pressures exerted by the culture of the institutional environment considered. In the present case, it may be relevant that Latin American countries are characterised by qualities such as individualism and regard for masculinity. In other words, in these societies individuals' main priorities tend to be themselves and their immediate family, and great importance is attached to individual initiative and achievement, focusing on the dominant values of success, money and material goods. Such institutional characteristics, however, do not favour the acceptance of female attitudes expressed by women in decision-making positions (Uribe-Bohorquez et al. 2019).

Taking into joint consideration the effects of normative and coercive pressures, our empirical evidence suggests there is a type II (institutional) compensation effect. In consequence, the advantages associated with the presence of a critical mass of female directors on the board, as discussed in Section 2.1, are negatively moderated by the Latin American context, in which normative pressures are antagonistic to perceptions of women directors as equal members of the board, forcing them to adopt more masculine stereotypes in order to obtain the approval of their colleagues. Under these circumstances, the presumed benefits for CSR of gender diversity are less likely to materialise, and the company's CSR commitment will be reduced. However, coercive pressures can mean that Latin American companies, which are mainly family businesses, will promote mechanisms of good governance, overcoming the weakness of their countries' legal systems. This counterbalancing effect, extrapolated to sustainability, suggests the companies will make a greater commitment to CSR. Overall, these contrary effects may cancel each other out, and thus no significant differences will be observed between the institutional environments considered.

We note, however, that the impact of normative cultural pressures is slightly stronger than the corrective effect of the family dimension of the firm, with respect to coercive pressures on the social and environmental dimensions of CSR. This condition would extrapolate the differences obtained by Uribe-Bohorquez et al. (2019) for business efficiency to other dimensions of corporate performance.

In relation to the control variables, larger companies that have active, large boards of directors and have created a specialist CSR committee perform more strongly from the social and environmental standpoints, and in terms of good governance. However, the presence of independent directors does not produce a homogeneous effect among the CSR dimensions considered. In relation to institutional pressures, at the country and sector levels, our results confirm the existence of mimetic effects, according to the indicators proposed by Amor-Esteban et al. (2018a, 2019). The effect of firm size differs from that of governance but it is common in our area and is applicable to different measures of company size (Dang et al. 2018).

\subsection{Robustness of Results}

To illustrate the robustness of our findings, Table 4 shows the results obtained for a sample exclusively composed of Latin American companies. In this sample, the "CriticalMass" variable has a positive effect, statistically significant at 99\% confidence, except in the case of Governance, where the confidence is $90 \%$. This confirms previous results on the influence on this variable on sustainable business performance. 
Table 4. Robustness of results in the Latin American sample.

\begin{tabular}{lcccc}
\hline & CSR & SOCIAL & ENV & GOV \\
\hline & $\begin{array}{c}\text { Coeff. } \\
\text { (Std.Error) }\end{array}$ & $\begin{array}{c}\text { Coeff. } \\
\text { (Std.Error) }\end{array}$ & $\begin{array}{c}\text { Coeff. } \\
\text { (Std.Error) }\end{array}$ & $\begin{array}{c}\text { Coeff. } \\
\text { (Std.Error) }\end{array}$ \\
\hline CriticalMass & $10.35^{* * *}$ & $11.72^{* * *}$ & $9.447^{* * *}$ & $4.401^{*}$ \\
& $(3.191)$ & $(3.453)$ & $(3.259)$ & $(2.485)$ \\
FF & 0.551 & 0.365 & 1.818 & -0.432 \\
& $(3.030)$ & $(3.358)$ & $(3.166)$ & $(2.648)$ \\
CriticalMass*FF & -7.619 & $-14.72^{* *}$ & $-14.80^{* *}$ & -3.927 \\
& $(6.842)$ & $(7.384)$ & $(6.949)$ & $(5.255)$ \\
\hline$n=22,958$ observations corresponding to 5124 companies for the period 2010-2016. ${ }^{* * *} p<0.01,{ }^{* *} p<0.05$, \\
${ }^{*} p<0.1$.
\end{tabular}

In this Latin American scenario, the "FF" variable is not significant in econometric terms in any of the models. This result is partially extensible to the "CriticalMass* ${ }^{*} F^{\prime}$ interaction, for which the effect is only statistically significant for the "SOCIAL" and "ENV" dimensions, at $95 \%$ confidence. These results are very similar to those obtained in the previous analyses.

\section{Complementary Results for a Weak Regulatory Environment}

The study results obtained are influenced by various factors. One such is the existence of normative pressures, derived from the traits of individualism and masculinity that characterise Latin American countries and which, in the institutional context, hamper the effective participation of women in policymaking (Uribe-Bohorquez et al. 2019). To isolate this effect, a complementary analysis was performed to determine whether the study findings could properly be extrapolated to other countries with similarly weak legal and investor protection systems (Amor-Esteban et al. 2018b). To do so, a specific factor was incorporated in a factor analysis containing the representative variables of common law countries, the level of investor protection, the efficiency of the judicial system and the law and order index proposed by La Porta et al. (1999). A dummy variable, "dWL", was then created for the countries with a value lower than the mean score obtained.

Table 5 shows that the "Critical Mass" and "FF" variables have the same impact as before. However, the effects of the interactions diverge, which corroborates the hypothesis that companies operating in Latin America are subject to a type II (institutional) compensation effect.

Table 5. Complementary results for a weak legal environment.

\begin{tabular}{ccccc}
\hline & CSR & SOCIAL & ENV & GOV \\
\hline & Coeff. & Coeff. & Coeff. & Coeff. \\
(Std.Error) & (Std.Error) & (Std.Error) & (Std.Error) \\
\hline CriticalMass & $7.017^{* * *}$ & $7.542^{* * *}$ & $7.225^{* * *}$ & $3.816^{* * *}$ \\
& $(0.614)$ & $(0.620)$ & $(0.623)$ & $(0.527)$ \\
FF & -1.246 & -0.797 & -0.603 & $-2.061^{* * *}$ \\
& $(0.880)$ & $(0.903)$ & $(0.934)$ & $(0.774)$ \\
CriticalMass*FF & -1.816 & $-4.334^{* * *}$ & -1.022 & -0.861 \\
& $(1.649)$ & $(1.664)$ & $(1.675)$ & $(1.417)$ \\
dWL & -0.789 & 1.000 & $1.852^{* *}$ & $-6.381^{* * *}$ \\
& $(0.784)$ & $(0.803)$ & $(0.828)$ & $(0.688)$ \\
CriticalMass ${ }^{*} \mathrm{dWL}$ & $-2.173^{*}$ & $-2.076^{*}$ & $-3.216^{* * *}$ & -0.651 \\
& $(1.142)$ & $(1.153)$ & $(1.161)$ & $(0.982)$ \\
FF $^{*} \mathrm{dWL}^{* *}$ & $3.733^{* * *}$ & 2.052 & 1.237 \\
CriticalMass*FF dWL & $2.844^{* *}$ & $(1.341)$ & $(1.385)$ & $(1.149)$ \\
& $(1.308)$ & $5.235^{* *}$ & 1.575 & $5.132^{* * *}$ \\
& 3.855 & $(2.379)$ & $(2.394)$ & $(2.026)$ \\
\hline
\end{tabular}

$n=22,958$ observations corresponding to 5124 companies for the period $2010-2016$. ${ }^{* * *} p<0.01$, ** $p<0.05$, ${ }^{*} p<0.1$. 


\section{Conclusions}

Many recent studies have addressed the question of CSR and the effects produced by institutional pressures derived from the cultural values of society and the degree of stakeholder protection offered under the legal system. Another area of interest is that of the role played by the company's decision makers in the application of CSR and the question of whether their decisions are influenced by the ownership structure.

The socio-emotional wealth (SEW) approach assumes that family businesses seek to preserve their SEW by maintaining and/or strengthening family control, influence and identity, emphasising family ties and continuing the family dynasty. From this perspective, family businesses are expected to be more strongly committed to CSR and to have a more favourable attitude towards investment in long-term sustainable projects, viewing these as an effective means of facilitating the transfer of the company to future generations, in addition to supporting and reinforcing its image and reputation (often closely associated with those of the family owners).

This paper examines the question of gender diversity, which is one of the essential characteristics of the board of directors and is directly relevant to its decision making in the field of CSR. According to the female stereotype, women are more likely than men to consider the interests of multiple stakeholders, and therefore present a greater commitment to CSR. In this study, we determine the conditions under which the benefits traditionally assumed to arise from gender diversity may lead to greater corporate sustainability.

Corroborating the Critical Mass theory, we find that the presence of at least three women on the board of directors is necessary for their opinions to be heard and for them to influence the decisions taken. These results suggest there is a need for a practical reorientation towards this minimum female presence, in order to ensure the practical implementation of its associated strengths and advantages, taking into account that individual boardroom members otherwise tend to follow the opinions of the majority.

A further consideration is the fact that for women to have a real impact in decision making there must be an appropriate environment, one that favours their contributions and produces the perception that they are full and equal members of the board. In this respect, researchers have highlighted the problems that may arise in practice for women's contributions to be recognised within the family firm, sometimes due to the existence of a male-oriented culture, according to which women must be 'protected'. The empirical evidence we present reveals the existence of these organisational barriers, although there is also a compensatory effect between the external and internal dimensions of SEW. From an econometric standpoint, this counterbalancing conceals the reality of differences between family and non-family firms regarding the influence of female directors of the board when they constitute a critical mass. On the other hand, in the dimension of good governance, the organisational environment has a moderating influence on the specific characteristics of family firms; in consequence, the promotion of values such as ethics and transparency, which tends to be fostered by gender diversity in the boardroom, is greater within family businesses. These results indicate that women directors in family businesses encourage the adoption of CSR practices, and that these decisions correct the prevalence of considerations of internal SEW (family control of management and executive positions) over those of external SEW (improving the company's image and reputation among minority investors and other stakeholders).

Finally, our consideration of the contingent effect of the institutional environment highlights the existence of a type II compensation effect derived from the role played by companies, mainly family firms, in correcting the weaknesses of the Latin American legal system, thus countering the culturally prevailing male stereotypes in this environment. However, this observation is qualified by the fact that, in the social and environmental dimensions of CSR, the coercive impact of normative cultural pressures is slightly greater than the corrective effect produced by the family nature of the firm.

From an academic standpoint, this study contributes to the literature on the theory of critical mass in the organisational environment of the family business. The conclusions 
drawn enhance our understanding of the role of female directors in this type of company. This focus is complemented by an analysis of the moderating role played by an environment characterised by a weak legal system and by informal structures of male authority.

In practical terms, our findings highlight the differential role played by female members of the board and identify the organisational and institutional environments that can foster (or hinder) their complete integration in company management.

Finally, this study presents certain limitations that should be addressed in future research. For example, it would be useful to examine whether board diversity in the family firm is affected by the sex of the founder's first child or by the percentage of female children in the family. Such an approach would also improve the analysis by controlling for exogenous shock.

Author Contributions: Conceptualization, I.-M.G.-S., L.R.-A. and M.C.G.-A.; methodology, I.-M.G.S.; software, I.-M.G.-S.; validation, I.-M.G.-S.; formal analysis, I.-M.G.-S.; investigation, I.-M.G.S.; resources, I.-M.G.-S., L.R.-A., M.-d.-C.G.-A.; data curation, I.-M.G.-S.; writing-original draft preparation, I.-M.G.-S., L.R.-A., M.d.-C.G.-A.; writing—review and editing, I.-M.G.-S., L.R.-A., M.d.C.G.-A.; visualization, I.-M.G.-S., L.R.-A., M.d.-C.G.-A.; supervision, I.-M.G.-S., L.R.-A., M.d.-C.G.-A.; project administration, I.-M.G.-S., L.R.-A.; funding acquisition, I.-d.-M.G.-S., L.R.-A., M.d.-C.G.-A. All authors have read and agreed to the published version of the manuscript.

Funding: Consejeria de Educacion, Junta de Castilla y Leon [Grant/Award No. SA069G18]; Ministerio de Ciencia e Innovacion [Grant/ Award No. ECO2013-43838P]; Ministerio de Ciencia, Innovacion y Universidades [Grant/Award No. RTI2018-093423-B-I00]; and Universidad de Salamanca [Grant/Award No. USAL2017-DISAQ]. The authors would like to thank the support of the Cátedra Santander de Empresa Familiar (Universidad de Granada) and the Accounting area (Universidad de Salamanca).

Data Availability Statement: The data are not publicly available. It could be obtained in Thomson Reuters international database by authorized access.

Conflicts of Interest: The authors declare no conflict of interest.

\section{References}

Almor, Tamar, Ofra Bazel-Shoham, and Sang Mook Lee. 2019. The dual effect of board gender diversity on RandD investments. Long Range Planning 101884. [CrossRef]

Amorelli, María-Florencia, and Isabel-María García-Sánchez. 2019. Critical mass of female directors, human capital and stakeholder engagement by corporate social reporting. Corporate Social Responsibility and Environmental Management. [CrossRef]

Amorelli, María-Florencia, and Isabel-María García-Sánchez. 2020. Trends in the dynamic evolution of board gender diversity and corporate social responsibility. Corporate Social Responsibility and Environmental Management 1-18. [CrossRef]

Amor-Esteban, Víctor, Ma-Purificación Galindo-Villardón, and Isabel-María García-Sánchez. 2018a. Useful information for stakeholder engagement: A multivariate proposal of an Industrial Corporate Social Responsibility Practices Index. Sustainable Development 26: 620-37. [CrossRef]

Amor-Esteban, Víctor, Isabel-María García-Sánchez, and Ma -Purificación Galindo-Villardón. 2018b. Analysing the effect of legal system on corporate social responsibility (CSR) at the country level, from a multivariate perspective. Social Indicators Research 140: 435-52. [CrossRef]

Amor-Esteban, Victor, Ma-Purificación Galindo-Villardón, and Fátima David. 2018c. Study of the importance of national identity in the development of corporate social responsibility practices: A multivariate vision. Administrative Sciences 8: 50. [CrossRef]

Amor-Esteban, Víctor, Mª-Purificación Galindo-Villardón, and Isabel-María García-Sánchez. 2019. A multivariate proposal for a National Corporate Social Responsibility Practices Index (NCSRPI) for International Settings. Social Indicators Research 143: 525-60. [CrossRef]

Amor-Esteban, Víctor, María Purificación Galindo-Villardón, and Isabel-María García-Sánchez. 2020. Bias in composite indexes of CSR practice: An analysis of CUR matrix decomposition. Corporate Social Responsibility and Environmental Management 27: 1914-36. [CrossRef]

Bansal, Shashank, Maria Victoria Lopez-Perez, and Lazaro Rodriguez-Ariza. 2018. Board independence and corporate social responsibility disclosure: The mediating role of the presence of family ownership. Administrative Sciences 8: 33. [CrossRef]

Basco, R., D. Cruz, K. Ramachandran, and F. Welter. 2015. Family Business in Emerging, Developing, and Transition Economies. Call for Papers-European Academy of Management Conference, June 17-20. Warsaw: Kozminski University.

Bear, Stephen, Noushi Rahman, and Corinne Post. 2010. The impact of board diversity and gender composition on corporate social responsibility and firm reputation. Journal of Business Ethics 97: 207-21. [CrossRef] 
Berrone, Pascual, Cristina Cruz, and Luis R. Gomez-Mejia. 2010. Socio-emotional wealth and corporate responses to institutional pressures: Do family-controlled firms pollute less? Administrative Science Quarterly 55: 82-113. [CrossRef]

Berrone, Pascual, Cristina Cruz, and Luis R. Gomez-Mejia. 2012. Socioemotional wealth in family firms: Theoretical dimensions, assessment approaches, and agenda for future research. Family Business Review 25: 258-79. [CrossRef]

Berrone, Pascual, Patricio Duran Luis Gómez-Mejía, Pursey P M A R Heugens, Tatiana Kostova, and Marc van Essen. 2020. Impact of informal institutions on the prevalence, strategy, and performance of family firms: A meta-analysis. Journal of International Business Studies. [CrossRef]

Bingham, John B., W. Gibb Dyer Jr., Isaac Smith, and Gregory L. Adams. 2011. A stakeholder identity orientation approach to corporate social performance in family firms. Journal of Business Ethics 99: 565-85. [CrossRef]

Binz, Claudia Astrachan, Keith E. Ferguson, Torsten M. Pieper, and Joseph H. Astrachan. 2017. Family business goals, corporate citizenship behaviour and firm performance: Disentangling the connections. International Journal of Management and Enterprise Development 16: 34-56. [CrossRef]

Birindelli, Giuliana, Stefano Dell'Atti, Antonia Patrizia Iannuzzi, and Marco Savioli. 2018. Composition and activity of the board of directors: Impact on ESG performance in the banking system. Sustainability 10: 4699. [CrossRef]

Boulouta, Ioanna. 2013. Hidden connections: The link between board gender diversity and corporate social performance. Journal of Business Ethics 113: 185-97. [CrossRef]

Boutchkova, Maria, Angelica Gonzalez, Brian G. M. Main, and Vathunyoo Sila. 2020. Gender diversity and the spillover effects of women on boards. Corporate Governance: An International Review 1-20. [CrossRef]

Briano-Turrent, Guadalupe, and Jannine Poletti-Hughes. 2017. Corporate governance compliance of family and non-family listed firms in emerging markets: Evidence from Latin America. Journal of Family Business Strategy 8: 237-47. [CrossRef]

Campopiano, Giovanna, and Alfredo De Massis. 2015. Corporate social responsibility reporting: A content analysis in family and non-family firms. Journal of Business Ethics 129: 511-34. [CrossRef]

Cascino, Stefano, Amedeo Pugliese, Donata Mussolino, and Chiara Sansone. 2010. The influence of family ownership on the quality of accounting information. Family Business Review 23: 246-65. [CrossRef]

Ceja, Lucía. 2018. El Papel de la Mujer en la Empresa Familiar: El Reconocimiento de un rol Crítico Pero a Veces Invisible. Cátedra de la Empresa Familiar. Barcelona: IESE, Pamplona: Universidad de Navarra.

Cennamo, Carmelo, Pascual Berrone, Cristina Cruz, and Luis R. Gomez-Mejia. 2012. Socioemotional wealth and proactive stakeholder engagement: Why family-controlled firms care more about their stakeholders. Entrepreneurship Theory and Practice 36: 1153-73. [CrossRef]

Chapple, Larelle, and Thu Phuong Truong. Truong. 2015. Continuous disclosure compliance: Does corporate governance matter? Accounting and Finance 55P: 965-88. [CrossRef]

Chen, Shuping, X. I. A. Chen, and Qiang Cheng. 2008. Do family firms provide more or less voluntary disclosure? Journal of Accounting Research 46: 499-536. [CrossRef]

Chrisman, James J., Pramodita Sharma, and Simon Taggar. 2007. Family influences on firms: An introduction. Journal of Business Research 60: 1005-11. [CrossRef]

Cook, Alison, and Christy Glass. 2018. Women on corporate boards: Do they advance corporate social responsibility? Human Relations 71: 897-924. [CrossRef]

Craig, Justin, and Clay Dibrell. 2006. The natural environment, innovation, and firm performance: A comparative study. Family Business Review 19: 275-88. [CrossRef]

Cruz, Cristina C., Luis R. Gómez-Mejia, and Manuel Becerra. 2010. Perceptions of benevolence and the design of agency contracts: CEO-TMT relationships in family firms. Academy of Management Journal 53: 69-89. [CrossRef]

Cuadrado-Ballesteros, Beatriz, Lázaro Rodríguez-Ariza, and Isabel-María García-Sánchez. 2015. The role of independent directors at family firms in relation to corporate social responsibility disclosures. International Business Review 24: 890-901. [CrossRef]

Cuadrado-Ballesteros, Beatriz, Lázaro Rodríguez-Ariza, Isabel-María García-Sánchez, and Jennifer Martínez-Ferrero. 2017. The mediating effect of ethical codes on the link between family firms and their social performance. Long Range Planning 50: 756-65. [CrossRef]

Dang, Chongyu, Zhichuan Frank Li, and Chen Yang. 2018. Measuring firm size in empirical corporate finance. Journal of Banking and Finance 86: 159-76. [CrossRef]

Dangelico, Rosa Maria, Alberto Nastasi, and Simone Pisa. 2019. A comparison of family and nonfamily small firms in their approach to green innovation: A study of Italian companies in the agri-food industry. Business Strategy and the Environment 28: 1434-48. [CrossRef]

de Holan, Pablo Martin, and Luis Sanz. 2006. Protected by the family? How closely held family firms protect minority shareholders. Journal of Business Research 59: 356-59. [CrossRef]

DeMartini, Paola. 2019. Why and how women in business can make innovations in light of the Sustainable Development Goals. Administrative Sciences 9: 64. [CrossRef]

Denis, Diane K., and John J. McConnell. 2003. International corporate governance. Journal of Financial and Quantitative Analysis 38: 1-36. [CrossRef]

DiMaggio, Paul J., and Walter W. Powell. 1983. The Iron Cage revisited: Institutional isomorphism and collective rationality in organizational fields. American Sociological Association 48: 147-60. [CrossRef] 
Dögl, Corinna, and Michael Behnam. 2015. Environmentally sustainable development through stakeholder engagement in developed and emerging countries. Business Strategy and the Environment 24: 583-600. [CrossRef]

Dyer, W. Gibb, Jr., and David A. Whetten. 2006. Family firms and social responsibility: Preliminary evidence from the SandP 500. Entrepreneurship Theory and Practice 30: 785-802. [CrossRef]

Fernández-Gago, Roberto, Laura Cabeza-García, and Mariano Nieto. 2016. Corporate social responsibility, board of directors, and firm performance: An analysis of their relationships. Review of Managerial Science 10: 85-104. [CrossRef]

Florensa, Luis Marcelo, Laura Márquez-Ramos, and María Luisa Recalde. 2015. The effect of economic integration and institutional quality of trade agreements on trade margins: Evidence for Latin America. Review of World Economics 151: 329-51. [CrossRef]

Górriz, Carmen Galve, and Vicente Salas Fumás. 1996. Ownership structure and firm performance: Some empirical evidence from Spain. Management and Decision Economics 17: 575-86. [CrossRef]

Garcia, Alexandre Sanches, Wesley Mendes-Da-Silva, and Renato J. Orsato. 2017. Sensitive industries produce better ESG performance: Evidence from emerging markets. Journal of Cleaner Production 150: 135-47. [CrossRef]

García-Sánchez, Isabel M. 2020a. Corporate Social Reporting and Assurance: The State of the Art. Spanish Accounting Review/Revista de Contabilidad. Available online: https:/ / papers.ssrn.com/sol3/papers.cfm?abstract_id=3588470 (accessed on 7 January 2021).

García-Sánchez, Isabel-María. 2020b. The moderating role of board monitoring power in the relationship between environmental conditions and corporate social responsibility. Business Ethics: A European Review 29: 114-29. [CrossRef]

García-Sánchez, Isabel-María, and Alejandra García-Sánchez. 2020. Corporate social responsibility during COVID-19 pandemic. Journal of Open Innovation: Technology, Market, and Complexity 6: 126. [CrossRef]

García-Sánchez, Isabel M., Luis Rodríguez Domínguez, and Isabel Gallego Álvarez. 2008. La influencia del consejo de administración en la adopción de un código ético. Revista de Contabilidad—Spanish Accounting Review 11: 93-120.

García-Sánchez, Isabel-María, Lázaro Rodríguez-Ariza, and José-Valeriano Frías-Aceituno. 2013. The cultural system and integrated reporting. International Business Review 22: 828-38. [CrossRef]

García-Sánchez, Isabel-Maria, Beatriz Cuadrado-Ballesteros, and Jose-Valeriano Frias-Aceituno. 2016. Impact of the institutional macro context on the voluntary disclosure of CSR information. Long Range Planning 49: 15-35. [CrossRef]

García-Sánchez, Isabel-María, Cristina Aibar-Guzmán, and Beatriz Aibar-Guzmán. 2020a. The effect of institutional ownership and ownership dispersion on eco-innovation. Technological Forecasting and Social Change 158: 120173. [CrossRef]

García-Sánchez, Isabel-María, Isabel Gallego-Álvarez, and José-Luis Zafra-Gómez. 2020b. Do independent, female and specialist directors promote eco-innovation and eco-design in agri-food firms? Business Strategy and the Environment 1-17. [CrossRef]

García-Sánchez, Isabel-María, Julia Martín-Moreno, Sana Akbar Khan, and Nazim Hussain. 2020c. Socio-emotional wealth and corporate responses to environmental hostility: Are family firms more stakeholder oriented? Business Strategy and the Environment 1-16. [CrossRef]

Gavana, Giovanna, Pietro Gottardo, and Anna Maria Moisello. 2019. What form of visibility affects earnings management? Evidence from Italian family and non-family firms. Administrative Sciences 9: 20. [CrossRef]

Giannarakis, Grigoris, George Konteos, and Nikolaos Sariannidis. 2014. Financial, governance and environmental determinants of corporate social responsible disclosure. Management Decision 52: 1928-51. [CrossRef]

Gómez-Mejía, Luis R., Katalin Takács Haynes, Manuel Núñez-Nickel, Kathyrn J. L. Jacobson, and José Moyano-Fuentes. 2007. Socioemotional wealth and business risk in family-controlled firms: Evidence from Spanish olive oil mills. Administrative Science Quarterly 52: 106-37. [CrossRef]

Gómez-Mejía, Luis R., Cristina Cruz, Pascual Berrone, and Julio De Castro. 2011. The bind that ties: Socioemotional wealth preservation in family firms. Academy of Management Annals 5: 653-707. [CrossRef]

Gómez-Mejía, Luis R., Rodrigo Basco, Ana Cristina Gonzalez, and Claudio G. Muller. 2020. Family business and local development in Iberoamerica. Cross Cultural and Strategic Management 27: 121-36. [CrossRef]

Hambrick, Donald C. 2007. The field of management's devotion to theory: Too much of a good thing? Academy of Management Journal 50: 1346-52. [CrossRef]

Hauswald, Hannes, and Andreas Hack. 2013. Impact of family control/influence on stakeholders' perceptions of benevolence. Family Business Review 26: 356-73. [CrossRef]

Hoffman, James, Mark Hoelscher, and Ritch Sorenson. 2006. Achieving sustained competitive advantage: A family capital theory. Family Business Review 19: 135-45. [CrossRef]

Kanter, Rosabeth Moss. 1977. Some effects of proportions on group life: Skewed sex ratios and responses to token women. American Journal of Sociology 82: 965-90. [CrossRef]

Kassinis, George, Alexia Panayiotou, Andreas Dimou, and Georgia Katsifaraki. 2016. Gender and environmental sustainability: A longitudinal analysis. Corporate Social Responsibility and Environmental Management 23: 399-412. [CrossRef]

Kidwell, Roland E., Franz W. Kellermanns, and Kimberly A. Eddleston. 2012. Harmony, justice, confusion, and conflict in family firms: Implications for ethical climate and the "fredo effect". Journal of Business Ethics 106: 503-17. [CrossRef]

Kim, Jaemin, Samantha Fairclough, and Clay Dibrell. 2017. Attention, action, and greenwash in family-influenced firms? Evidence From polluting industries. Organization E Environment 30: 304-23. [CrossRef]

Koh, Ping-Sheng, Cuili Qian, and Heli Wang. 2014. Firm litigation risk and the insurance value of corporate social performance. Strategic Management Journal 35: 1464-82. [CrossRef] 
Kolev, Kalin D., and Gerry McNamara. 2020. Board demography and divestitures: The impact of gender and racial diversity on divestiture rate and divestiture returns. Long Range Planning 53: 101881. [CrossRef]

Kuschel, Katherina. 2019. Women founders in the technology industry: The startup-relatedness of the decision to become a mother. Administrative Sciences 9: 30. [CrossRef]

La Porta, Rafael, Florencio Lopez-de-Silanes, and Andrei Shleifer. 1999. Corporate ownership around the world. The Journal of Finance 54: 471-517. [CrossRef]

Li, Zhichuan Frank. 2018. A Survey of Corporate Social Responsibility and Corporate Governance. Research Handbook of Finance and Sustainability. Edited by Sabri Boubaker, Douglas Cumming and Duc K. Nguyen. Cheltenham: Edward Elgar Publishing.

Li, Frank, Taylor Morris, and Brian Young. 2019. The effect of corporate visibility on corporate social responsibility. Sustainability 11: 3698. [CrossRef]

Lins, Karl V., Henri Servaes, and Ane Tamayo. 2017. Social capital, trust, and firm performance: The value of corporate social responsibility during the financial crisis. The Journal of Finance 72: 1785-823. [CrossRef]

Malik, Mahfuja. 2015. Value-enhancing capabilities of CSR: A brief review of contemporary literature. Journal of Business Ethics 127: 419-38. [CrossRef]

Marques, Pilar, Pilar Presas, and Alexandra Simon. 2014. The heterogeneity of family firms in CSR engagement: The role of values. Family Business Review 27: 206-27. [CrossRef]

Michelon, Giovanna, and Antonio Parbonetti. 2012. The effect of corporate governance on sustainability disclosure. Journal of Management and Governance 16: 477-509. [CrossRef]

Miller, Danny, and Isabelle Le Breton-Miller. 2006. Family governance and firm performance: Agency, stewardship, and capabilities. Family Business Review 19: 73-87. [CrossRef]

Minárová, Martina, Denisa Malá, and Filip Smutný. 2020. Emotional intelligence of managers in family businesses in Slovakia. Administrative Sciences 10: 84. [CrossRef]

Neubaum, Donald O., Clay Dibrell, and Justin B. Craig. 2012. Balancing natural environmental concerns of internal and external stakeholders in family and non-family businesses. Journal of Family Business Strategy 3: 28-37. [CrossRef]

North, Douglass C. 1990. A transaction cost theory of politics. Journal of Theoretical Politics 2: 355-67. [CrossRef]

O'Boyle, Ernest H., Jr., Matthew W. Rutherford, and Jeffrey M. Pollack. 2010. Examining the relation between ethical focus and financial performance in family firms: An exploratory study. Family Business Review 23: 310-26. [CrossRef]

Orlitzky, Marc, Frank L. Schmidt, and Sara L. Rynes. 2003. Corporate social and financial performance: A meta-analysis. Organization Studies 24: 403-41. [CrossRef]

Payne, G. Tyge, Curt B. Moore, Stanley E. Griffis, and Chad W. Autr. 2011. Multilevel challenges and opportunities in social capital research. Journal of Management 37: 491-520.

Pérez-Batres, Luis A., Van V. Miller, and Michael J. Pisani. 2011. Institutionalizing sustainability: An empirical study of corporate registration and commitment to the United Nations global compact guidelines. Journal of Cleaner Production 19: 843-51. [CrossRef]

Pérez-Pérez, Marta, María Concepción López-Férnandez, and María Obeso. 2019. Knowledge, renewal and flexibility: Exploratory research in family firms. Administrative Sciences 9: 87. [CrossRef]

Poletti-Hughes, Jannine, and Beatriz Martínez-Garcia. 2020. Leverage in family firms: The moderating role of female directors and board quality. International Journal of Finance and Economics 1-17. [CrossRef]

Post, Corinne, Noushi Rahman, and Emily Rubow. 2011. Green governance: Boards of directors' composition and environmental corporate social responsibility. Business and Society 50: 189-223. [CrossRef]

Reyes-Bastidas, Carolina, and Guadalupe del Carmen. Briano-Turrent. 2018. Las mujeres en posiciones de liderazgo y la sustentabilidad empresarial: Eviencia de empresas cotizadas de Colombia y Chile. Estudios Gerenciales 34: 385-98. [CrossRef]

Rigby, Mike, and Enric Sanchís. 2006. The concept of skill and its social construction. European Journal of Vocational Training 37: 22-33.

Rodríguez Zapatero, Maribel, and Magdalena Rodríguez Jiménez. 2011. La mujer en la empresa familiar. Revista de Empresas Familiar 1: 17-26. [CrossRef]

Rodríguez-Gómez, Sara, Maria Lourdes Arco-Castro, Maria Victoria Lopez-Perez, and Lazaro Rodríguez-Ari. 2020. Where does CSR come from and where does it go? A review of the state of the art. Administrative Sciences 10: 60. [CrossRef]

Setó-Pamies, Dolors. 2015. The relationship between women directors and corporate social responsibility. Corporate Social Responsibility and Environmental Management 22: 334-45. [CrossRef]

Sharma, Pramodita. 2004. An overview of the field of family business studies: Current status and directions for the future. Family Business Review 17: 1-36. [CrossRef]

Sharma, Pramodita, and Mattias Nordqvist. 2008. A classification scheme for family firms: From family values to effective governance to firm performance. In Family Values and Value Creation. Edited by Josep Tàpies and John L. Ward. A Family Business Publication. London: Palgrave Macmillan.

Sharma, Pramodita, and Sanjay Sharma. 2011. Drivers of proactive environmental strategy in family firms. Business Ethics Quarterly 21: 309-34. [CrossRef]

Singla, Chitra, Rajaram Veliyath, and Rejie George. 2014. Family firms and internationalization-governance relationships: Evidence of secondary agency issues. Strategic Management Journal 35: 606-16. [CrossRef]

Stavrou, Eleni, George Kassinis, and Alexis Filotheou. 2007. Downsizing and stakeholder orientation among the Fortune 500: Does family ownership matter? Journal of Business Ethics 72: 149-62. [CrossRef] 
Tajfel, Henri. 1982. Social psychology of intergroup relations. Annual Review of Psychology 33: 1-39. [CrossRef]

Terrón-Ibáñez, Sara, María Elena Gómez-Miranda, María del Mar Miras Rodríguez, and Lázaro Rodríguez Ariza. 2019. Radiografía Económico-Financiera de las pequeñas empresas familiares españolas: Economic and Financial Snapshot of small spanish family firms. Revista De Contabilidad-Spanish Accounting Review 22: 21-31. [CrossRef]

Torchia, Mariateresa, Andrea Calabrò, and Morten Huse. 2011. Women directors on corporate boards: From tokenism to critical mass. Journal of Business Ethics 102: 299-317. [CrossRef]

Tsui, Anne S., Lyman W. Porter, and Terri D. Egan. 2002. When both similarities and dissimilarities matter: Extending the concept of relational demography. Human Relations 55: 899-929. [CrossRef]

Urbaníková, Marta, Michaela Štubňová, Viera Papcunová, and Jarmila Hudáko. 2020. Analysis of innovation activities of Slovak small and medium-sized family businesses. Administrative Sciences 10: 80. [CrossRef]

Uribe-Bohorquez, María Victoria, Jennifer Martínez-Ferrero, and Isabel-María García-Sánchez. 2019. Women on boards and efficiency in a business-orientated environment. Corporate Social Responsibility and Environmental Management 26: 82-96. [CrossRef]

Valls Martínez, María del Carmen, Pedro Antonio Martín Cervantes, and Salvador Cruz Rambaud. 2020. Women on corporate boards and sustainable development in the American and European markets: Is there a limit to gender policies? Corporate Social Responsibility and Environmental Management 27: 2642-56. [CrossRef]

Vázquez, Pedro., Isabel C. Botero, Unai Arzubiaga, and Esra Memili. 2020. Family business in Latin America. Call for Papers of Special Issue in Journal of Family Business Strategy. Available online: https://www.journals.elsevier.com/journal-of-family-businessstrategy/call-for-papers / family-business-in-latin-america (accessed on 7 January 2021).

Wang, Qian, Junsheng Dou, and Shenghua Jia. 2015. A meta-analytic review of corporate social responsibility and corporate financial performance: The moderating effect of contextual factors. Bussiness $\mathcal{E}$ Socciety 55: 1-39.

Wei, Feng, Binyan Ding, and Yu Kong. 2017. Female directors and corporate social responsibility: Evidence from the environmental investment of Chinese listed companies. Sustainability 9: 2292. [CrossRef]

Wiseman, Robert M., and Luis R. Gómez-Mejía. 1998. A behavioral agency model of managerial risk taking. Academy of Management Review 23: 133-53. [CrossRef]

Young, Gary J., Yvonne Stedham, and Rafik I. Beekun. 2000. Boards of directors and the adoption of a CEO performance evaluation process: Agency-And Institutional-Theory perspectives. Journal of Management Studies 37: 277-96. [CrossRef] 